Заячківська О. В., к.е.н., доцент, Яскал Я. А., магістр, (Національний університет водного господарства та природокористування, м. Рівне)

\title{
РОЛЬ ФІНАНСОВОЇ СТІЙКОСТІ ПІДПРИЕМСТВА В УМОВАХ ФІНАНСОВО-ЕКОНОМІЧНОЇ КРИЗИ
}

У статті досліджено значущість категорії «стійкість» в аналізі фінансового стану підприємства при умовах фінансово-економічної кризи. Розглянуто наукові підходи щодо з'ясування сутності фінансової стійкості, ролі і значення. Проаналізовано методики оцінки показників фінансової стійкості підприємства. Обґрунтовано важливість рівня та перспективних напрямів підвищення ефективності управління фінансовою стійкістю в умовах фінансово-економічної кризи. Основну увагу приділено необхідності своєчасного аналізу фінансової стійкості окремих господарюючих суб'єктів.

Ключові слова: фінансова стійкість, платоспроможність, система показників, критерії оцінки, складові фінансової стійкості, стабільний розвиток, фактори впливу.

Найголовнішою проблемою сьогодні для України $є$ економічна криза та її загострення на фоні нестабільної політичної та демографічної ситуації. За ці роки економіка України прийняла на себе низку випробувань, зумовлених падінням попиту на товари і послуги, відсутністю стимулу до модернізації виробництва. Багато підприємств закриваються від нестачі фінансових засобів, що відображається на динаміці податкових надходжень у місцеві та державний бюджети [6, C. 48].

Поруч зі зниженням платоспроможності вітчизняних підприємств спостерігається зниження їх фінансової стійкості та зростання кількості банкрутств. Тож набуває популярності пошук антикризових заходів щодо підвищення фінансової стійкості підприємств України.

У країнах Європейського Союзу підвищення фінансової стійкості підприємств формується інструментами кризового менеджменту, які не тільки виконують функції з ліквідації ризиків та загроз діяльності підприємств, а й сприяють їх попередженню на ранніх стадіях виникнення кризових явищ. Саме превентивна форма гарантування фінансової стійкості $є$ найбільш ефективною в антикризовому регулюванні та управлінні та потребує використання системного підходу, 
який охоплює в собі систему планування поточної діяльності, реагування на фактори зовнішнього та внутрішнього середовища, виявлення основних ризиків поточної діяльності та забезпечення неперервності ведення господарської діяльності [1, С. 25].

Основні аспекти визначення та аналізу фінансової стійкості підприємства досліджувались зарубіжними науковцями. Серед них слід назвати таких, як Е. Альтман, Е. Дж. Долан, Дж. К. Ван Хорн, І. Бланк, В.В. Іванов, Є.І. Уткін. Широкий спектр питань управління фінансовою стійкістю підприємства та розробки підходів до оцінювання фінансової безпеки розкрито в працях вітчизняних науковців, таких як О.І. Барановський, В.О. Василенко, О.Д. Заруба, А.М. Поддєрьогін, С.В. Мішина, Г.В. Савицька [3, С. 34].

Метою дослідження є зображення підходів щодо врегулювання фінансової стійкості підприємства в умовах фінансово-економічної кризи, окресленні методів та норм, що є найбільш ефективними в антикризовому управлінні фінансовою стійкістю підприємства.

Досягнення зазначеної мети обумовило необхідність вирішення таких завдань:

- дослідити фінансову стійкість як комплексну категорію стабільного функціонування підприємства;

- визначити головні складові фінансової стійкості підприємства вцілому;

- окреслити механізм фінансової стійкості підприємства у період кризи;

- оцінити економічний ефект від впровадження методів фінансової стійкості на підприємстві в період економічної кризи [5, С. 67].

Щодо фінансової стійкості, її слід зображати як комплексну категорію, котра розглядає, з одного боку, суто внутрішні елементи забезпечення стабільності (безперебійний процес виробництва та реалізації товарів, стабільне отримання прибутку, своєчасна сплата кредиторських платежів), а з іншого боку, у розрізі більш загальному, передбачає стабільне функціонування підприємства в мінливих умовах, котрі часто носять дестабілізуючий характер. Фінансову стійкість можна визначити як стан підприємства, який характеризується збалансованим використанням фінансових ресурсів, наявністю оптимального співвідношення між власними та залученими коштами, збереженні господарської самостійності за умови нестабільності зовнішнього середовища, що веде до стабільного функціонування підприємства з позитивними перспективами розвитку [7, С. 35].

Усі види стійкості та безпосередньо фінансова стійкість підприємства у контексті забезпечення ефективності діяльності у стратегічному масштабі повинні стати об'єктами постійного моніторингу 3 
боку управлінського персоналу підприємства. Стійкість розвитку промислового підприємства необхідно оцінювати на основі аналітичних процедур з урахуванням особливостей його діяльності та цілей, які необхідно реалізувати в запланованому періоді.

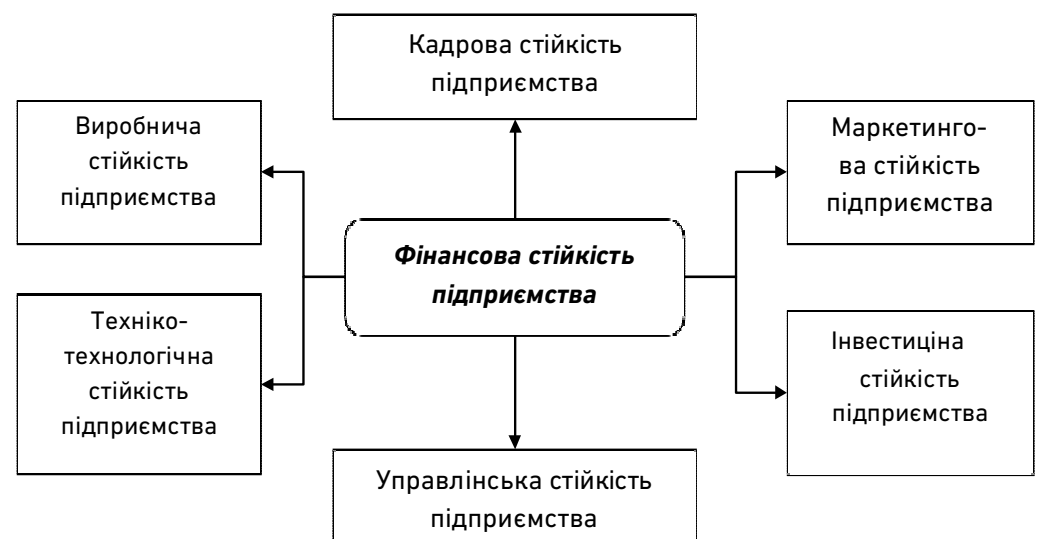

Рис. 1. Складові фінансової стійкості підприємства

Головною компонентою стійкості підприємства є його фінансова стійкість (рис. 1), за рахунок якої підприємство спроможне забезпечувати маркетингову та кадрову стійкість, сприяти розвитку виробничої та техніко-технологічної стійкості, підтримувати інвестиційну стійкість, підвищувати ефективність процесу управління [4, С. 114]. Отже, фінансова стійкість підприємства стає запорукою стабільного функціонування та розвитку підприємства.

Основними резервами підвищення фінансової стійкості підприємства для створення умов необхідних для стабільного функціонування і розвитку сучасного підприємства є:

- оптимізація структури капіталу підприємства. Цей напрям полягає у визначенні оптимального співвідношення власного та позичкового капіталу підприємства, адже формування оптимальної структури капіталу для фінансування необхідного обсягу затрат та забезпечення бажаного рівня доходів $є$ одним із найважливіших завдань на підприємстві;

- підвищення ефективності використання активів. Збалансована організація оборотних і необоротних активів справляє великий вплив на результативність і ефективність роботи підприємства, його фінансову стійкість

- використання фінансового планування. Забезпечення ритмічної та ефективної роботи підприємства, а саме: розробка бізнес-плану, фінансового плану; контроль і аналіз виконання цих планів; вживання конкретних заходів щодо фінансово-господарської стабілізації [9, 
C. 258].

Якщо підприємство фінансово стійке, то воно має перевагу перед іншими підприємствами того ж профілю щодо залучень інвестицій, отримання кредитів, вибору постачальників та підбору кваліфікованих кадрів. Узагальнюючи, можна зробити висновок, що фінансову стійкість слід розглядати як особливий збалансований стан рівноваги підприємства, за якого відбувається раціональне використання виробничих та фінансових ресурсів, що дозволяє забезпечити його стабільне функціонування та розвиток, за наявності складних дестабілізуючих умов його середовища [8, С. 240].

Такий стан досягається шляхом оптимізації основних фінансових показників підприємства, а саме рентабельності, платоспроможності та кредитоспроможності. Важливим питанням також є збалансування структури капіталу підприємства відповідно до стадії його розвитку задля забезпечення його економічної ефективності. У процесі здійснення господарської діяльності підприємство зазнає комплексного впливу різноманітних факторів, існування яких напряму пов'язане з певними ризиками.

1. Гринкевич С. С. Економічні основи стратегічного управління фінансовою стійкістю підприємства в умовах ринкових перетворень. Науковий вісник НЛТУ України. 2014. Вип. 18.5. С. 110-114. 2. Економіка підприємства. Збірник практичних задач і конкретних ситуацій : навч. посібник / С. Ф. Покропивний, Г. О. Швиданенко, О. С. Федонін та ін. ; за ред. д-ра екон. наук, проф. С. Ф. Покропивного. К. : КНЕУ, 2015. 328 с. 3. Ковалев А. И., Привалов В. П. Анализ финансового состояния предприятия. 2-е изд., пераб., доп. М. : Центр экономики и маркетинга, 2002. 188 с. 4. Крухмаль О. В., Коваленко В. В. Антикризове управління в забезпеченні фінансової стійкості банківської системи : монографія. Суми : УАБС НБУ, 2014. 198 с. 5. Муза И. М. Проблеми розвитку фінансової стійкості підприємства в сучасній економіці. Экономика. Финансовые отношения. URL: http://www.rusnauka.com (дата звернення: 15.11.2018). 6. Павловська О. В., Притуляк Н. М., Невмержицька Н. Ю. Фінансовий аналіз : навч.-метод. посіб. для самост. вивч. дисц. К. : КНЕУ, 2012. 388 с. 7. Савицька Г. В. Економічний аналіз діяльності підприємства : навч. посіб. 2-ге видан., випр. і доп. К., 2015. 662 с. 8. Фролова Т. О. Фінансовий аналіз : навч.-метод. посіб. для самост. вивч. К. : Вид-во Европ. ун-ту, 2005. 253 с. 9. Цал-Цалко Ю. С. Фінансовий аналіз : підручник. К. : Центр учбової літератури, 2016. 566 с.

\section{REFERENCES:}

1. Hrynkevych S. S. Ekonomichni osnovy stratehichnoho upravlinnia finansovoiu stiikistiu pidpryiemstva $v$ umovakh rynkovykh peretvoren. Naukovyi visnyk NLTU Ukrainy. 2014. Vyp. 18.5. S. 110-114. 2. Ekonomika 
pidpryiemstva. Zbirnyk praktychnykh zadach i konkretnykh sytuatsii : navch. posibnyk / S. F. Pokropyvnyi, H. O. Shvydanenko, O. S. Fedonin ta in. ; za red. dra ekon. nauk, prof. S. F. Pokropyvnoho. K. : KNEU, 2015. 328 s. 3. Kovalev A. Y., Privalov V. P. Analiz finansovoho sostoianiia predpriiatiia. 2-ie izd., perab., dop. M. : Tsentr ekonomiki i marketinha, 2002.188 s. 4. Krukhmal O. V., Kovalenko V. V. Antykryzove upravlinnia $\mathrm{v}$ zabezpechenni finansovoi stiikosti bankivskoi systemy : monohrafiia. Sumy : UABS NBU, 2014. 198 s. 5. Muza Y. M. Problemy rozvytku finansovoi stiikosti pidpryiemstva v suchasnii ekonomitsi. Ekonomika. Finansovyie otnosheniia. URL: http://www.rusnauka.com (data zvernennia: 15.11.2018). 6. Pavlovska 0. V., Prytuliak N. M., Nevmerzhytska N. Yu. Finansovyi analiz : navch.-metod. posib. dlia samost. vyvch. dysts. K. : KNEU, 2012. 388 s. 7. Savytska H. V. Ekonomichnyi analiz diialnosti pidpryiemstva : navch. posib. 2-he vydan., vypr. i dop. K., 2015. 662 s. 8. Frolova T. 0. Finansovyi analiz : navch.-metod. posib. dlia samost. vyvch. K. : Vyd-vo Evrop. un-tu, 2005. 253 s. 9. Tsal-Tsalko Yu. S. Finansovyi analiz : pidruchnyk. K. : Tsentr uchbovoi literatury, 2016. $566 \mathrm{~s}$.

Рецензент: к.е.н., доцент Мельник Л. В. (НУВГП)

Zaiachkivska O. V., Candidate of Economics (Ph.D.), Associate Proffesor, Yaskal Ya. A., Master (National University of Water and Environmental Engineering, Rivne)

\section{ROLE OF FINANCIAL STABILITY OF THE ENTERPRISE IN CONDITIONS OF FINANCIAL AND ECONOMIC CRISIS}

The article substantiates the importance of the category of "stability" in the analysis of the financial condition of the enterprise in the financial and economic crisis, examines the scientific approaches to clarify its nature, role and importance, the methodology for assessing its level and identify promising areas to improve the effectiveness of its management. The problem of financial sustainability of enterprises, operating in a market economy, is among the most important not only financial, but also economic problems, so this article considers the theoretical approaches to the definition of the economic content of the notion "financial stability of an enterprise", disclosed the value and necessity of its analysis in market conditions. Poorly studied in scientific works of questions remain communication financial stability with the other components of the financial condition of the enterprise, which clearly shown in this article. Lists the factors and symptoms, which is determined and depends on a financially sustainable enterprise. The main attention is paid to the need for a 
timely analysis of the financial soundness of individual economic entities. Defined role of the financial stability of the enterprise for sustainable development, both individual enterprises and society as a whole. In scientific literature there is no single view on the essence of the category "financial stability", the analysis of scientific-methodical sources illustrates the ambiguities in the definition of this concept is, therefore, suggested that systematic and generalized definition of financial stability of the enterprise. Funds of operative neutralization of risk of decline of financial firmness are here provided, recommendations are given in relation to the use of indexes for estimation of financial firmness. The result of this analysis has shown us that financial stability emerges as a major precondition and result of providing financial security of the company.

Keywords: financial stability of the enterprise, solvency, system of indicators, evaluation criteria, components of financial stability, stable development, factors of influence.

Заячкивская О. В., к.э.н., доцент, Яскал Я. А., магистр

(Национальный университет водного хозяйства и природопользования, г. Ровно)

\section{РОЛЬ ФИНАНСОВОЙ СТОЙКОСТИ ПРЕДПРИЯТИЯ В УСЛОВИЯХ ФИНАНСОВО-ЭКОНОМИЧЕСКОГО КРИЗИСА}

В статье исследована значимость категории «стойкость» в анализе финансового состояния предприятия при финансовоэкономическом кризисе. Рассмотрены научные подходы о сущности финансовой стойкости, роли и значения. Проанализировано методику оценки показателей финансовой стойкости предприятия. Обоснована важность уровня и перспективных направлений повышения эффективности управления финансовой стойкости в условиях финансово-экономического кризиса. Основное внимание уделено необходимости своевременного анализа финансовой стойкости отдельных хозяйствующих субъектов.

Ключевые слова: финансовая стойкость, платежеспособность, система показателей, критерии оценки, составляющие финансовой стойкости, стабильное развитие, фактор влияния. 